\title{
Genomic evaluation for wellness traits in US Jersey cattle
}

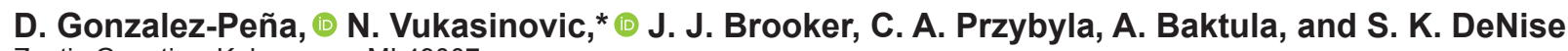 \\ Zoetis Genetics, Kalamazoo, Ml 49007
}

\section{ABSTRACT}

The number of Jersey cows in the United States has been steadily increasing in recent years according to Council on Dairy Cattle Breeding statistics. To help producers reduce the risk of health disorders in their Jersey animals, Zoetis has developed genomic predictions for wellness traits in Jersey cattle using producerrecorded data. The traits included mastitis (MAST), metritis, retained placenta, displaced abomasum (DA), ketosis, lameness, and milk fever in cows and respiratory disease, scours, and calf livability (DEAD) in calves. Phenotypic data on health events, pedigree, and genotypes were collected directly from producers upon obtaining their permission. Each trait was defined as a binary event, having a value of 1 if an animal has been recorded with a disorder and 0 otherwise. The number of phenotypic records ranged from 216,166 for DA to 628,958 for MAST for cow traits and from 186,505 for scours to 380,429 for DEAD for calf traits. The number of genotyped animals was 41,271. All traits were analyzed using a univariate threshold animal model. The model for cow wellness traits included the fixed effect of parity and random effects of herd $\times$ year $\times$ season of calving, animal, and permanent environment. The model for calf wellness traits included the fixed effect of year of birth $\times$ calving season $\times$ region and random effects of herd $\times$ year of birth and animal. A total of 45,163 SNP were used in genomic analyses. Animals genotyped with low-density chips were imputed to the required number of markers. All analyses were based on the single-step genomic BLUP. Heritabilities ranged from 0.061 for DA to 0.120 for lameness. Predicted transmitting abilities were expressed in percentage points as deviations from the average estimated probability of a disorder in the base population. Reliabilities of genomic predicted transmitting abilities had average values between $32 \%$ (DA) and 51\% (MAST and DEAD). The results indicate that a direct evaluation of cow and calf wellness traits under a genomic threshold

Received May 3, 2019

Accepted October 17, 2019

*Corresponding author: natascha.vukasinovic@zoetis.com model is feasible and offers predictions with average reliabilities comparable with other lowly heritable traits for Jersey cattle.

Key words: wellness trait, Jersey, genomic prediction

\section{INTRODUCTION}

The number of Jersey cows in the United States has been steadily increasing in recent years. In 2018, more than 338,697 Jersey cows from 818 herds were enrolled in production testing programs, representing $8.7 \%$ of the total number of cows enrolled in DHIA test plans reported by the Council on Dairy Cattle Breeding (CDCB; CDCB, 2018a; Dürr and Norman, 2018). In the last decade, from January 2009 to January 2019, the number of genotyped Jerseys in the CDCB database increased from 2,190 to 316,269 (i.e., more than 144-fold; CDCB, 2019b).

Selecting for more efficient animals has been a predominant breeding goal of the dairy industry for the last century, with an emphasis on production traits (Miglior et al., 2017). However, negative side effects of this trend caused a shift in dairy genetics (Rauw et al., 1998; Oltenacu and Broom, 2010), creating a need for selection on functional traits, including fertility and health (Miglior et al., 2005). Increasing economic pressure has moved many dairy producers to switch from traditional Holsteins to other dairy breeds, such as Jerseys. Jersey cows are perceived to make more profit per acre (Kumar et al., 2015) and to produce the same amount of protein using fewer resources and generating less waste relative to larger dairy breeds (Capper and Cady, 2012). Olson et al. (2010) compared feed intake and production of Holsteins, Jerseys, and their crosses and observed that Jerseys were $6 \%$ better than Holsteins at converting input to output. Moreover, Jerseys were found to stay longer in the herd than other dairy breeds (Nieuwhof et al., 1989). Jersey cows are also known for having fewer calving difficulties (Yao et al., 2014), less disease and injury, and fewer foot and leg problems than other dairy breeds (US Jersey, 2016). However, the health and wellness of Jersey cows may deteriorate under the selection pressure aimed at increasing milk yield and solids and intensive management practices on large commercial dairies. Olson et 
al. (2011) found that purebred Jerseys were 21.5 times more likely to get mastitis than purebred Holsteins, although they were less likely than Holsteins to get metritis, displaced abomasum, or ketosis. Because Jersey calves are characterized by small size and very little body fat reserve (Pedraza and Vigil, 2014), they may be more prone to calfhood diseases and exhibit higher mortality than Holstein calves. Ballou (2012) found that Jersey calves had a lower innate immune response than Holstein calves despite having higher total serum protein concentration, indicating that they may be at higher relative risk of morbidity.

Breeding heifers for replacement represents $20 \%$ of total production costs in dairy systems (Gabler et al., 2000). Generally, an animal may be considered repaid for the cost of rearing only when it completes the first 2 lactations (Waltner-Toews et al., 1986; Bach, 2011; Boulton et al., 2017). Selecting animals with the greatest disease resistance will decrease the proportion of involuntary culling before the second lactation and thus decrease overall production costs (Hertl et al., 2018). The genomic predictions for wellness traits could help reduce the cost associated with mastitis ( $\$ 444$ per case in US dairy cattle; Rollin et al., 2015), milk fever (\$334 per case in US dairy cattle; Guard, 1996), or lameness ( $\$ 177.62$ per case in US dairy cattle; Cha et al., 2010) in the profitability equation. Therefore, improving health and wellness in Jersey cattle through direct genetic selection presents a compelling opportunity for dairy producers to help manage disease incidence and improve profitability of their herds when coupled with sound management practices.

Selecting and breeding animals that are less susceptible to diseases have a long tradition in Nordic countries, where recording of health information dates back to 1970 and the routine genetic evaluation for health traits started in early 2000 (Heringstad et al., 2000; Philipsson and Lindhé, 2003; Rius-Vilarrasa et al., 2018). Canada included mastitis in the national genomic evaluation in 2014 (Jamrozik et al., 2013), and the Canadian Dairy Network released a metabolic disease-resistance index (Jamrozik et al., 2016) and a hoof health index for Holsteins in 2018 (Beavers and Van Doormaal, 2018). In the United States, the inclusion of health and wellness traits in routine genetic evaluation has been hampered by a lack of standardized health data recording. However, research has shown that usable genetic predictions can be obtained using producer-recorded data, even if they were not collected by trained personnel (Zwald et al., 2004a,b; Koeck et al., 2012; Neuenschwander et al., 2012; Parker Gaddis et al., 2014; McNeel et al., 2017; Vukasinovic et al., 2017; Gonzalez-Peña et al., 2019). The first commercially available genetic and genomic evaluation for dairy wellness traits in the United States was introduced by Zoetis Genetics in 2016 (Vukasinovic et al., 2017), followed by the CDCB (Nicolazzi et al., 2018). However, so far in the United States, predictions from Zoetis and CDCB for wellness traits are available only for the Holstein breed. Therefore, the objectives of this study were (1) to estimate variance components and heritabilities of wellness traits in Jersey cattle, (2) to develop genomic predictions for cow and calf wellness traits for Jersey cattle based on producer-recorded data and single-step genomic BLUP (ssGBLUP) methodology, and (3) to obtain correlations among wellness traits and the traits in the US national dairy genetic evaluation for Jersey cattle.

\section{MATERIALS AND METHODS}

\section{Phenotypes}

Phenotypic data were obtained directly from producers upon obtaining their written permission to use data for research and development as well as for commercial purposes. As of January 2019, 90 herds located in 20 states were providing phenotypic data for the genetic evaluation of Jersey cattle; 37 of the herds, contributing $65 \%$ of the animals with phenotypes in the analysis, were located in California.

Similar to the strategy of acquisition of Holstein data (Vukasinovic et al., 2017; Gonzalez-Peña et al., 2019), backup files produced using herd management software were delivered to Zoetis, opened, and processed using internally written scripts. Pedigree information was extracted from the backup files and updated based on the genomic information available.

Health events of interest were extracted from the herd management software backup files. Cow wellness traits [mastitis (MAST), metritis (METR), retained placenta (RETP), displaced abomasum (DA), ketosis (KETO), lameness (LAME), and milk fever (MFV)] and calf wellness traits [calf respiratory disease (RESP), calf scours (DIAR), and calf livability (DEAD)] were considered (Table 1). Each trait was defined as a binary event, with a value of 1 if an animal has been recorded with the problem at any point during the lactation or a determined time period as a calf and 0 otherwise, regardless of how many times disease incidence or treatment was recorded.

For cow traits, each animal was required to have a lactation record with a valid calving date and lactation number and a calving interval between 250 and $999 \mathrm{~d}$. Lactations of the same cow without recorded disorders, as well as lactations of all not-recorded herd mates of an animal, were added as "healthy" records. Phenotype 
records were checked against the pedigree, and all animals found to be male in the pedigree file or having a calving date preceding their birth date were removed. Records were also removed if an animal was in her current lactation and did not reach an opportunity period, which was defined as DIM by which $90 \%$ of all cases of a particular disorder have been recorded, or if they exceeded the upper threshold of DIM that was set to the highest number of DIM when the occurrence of a disorder was biologically plausible. For calf traits, the opportunity period was defined as the upper age limit for each trait. Animals not reaching the opportunity period were removed from the analysis regardless of whether they were healthy or sick. Calves with disorders recorded outside the age range defined in Table 1 were considered healthy for that trait regardless of what happened to them or how long they stayed in the herd after the defined time period had passed. This was done to prevent inflation of sick or healthy records.

Contemporary groups were created by combining the herd, year, and season of calving. For all cow traits, each group was required to have a minimum of 20 lactation records and at least 1 recording of a disorder; otherwise, the entire group was discarded $(<1 \%$ of the total records). For calf traits, herd by year groups with fewer than 10 records were removed, as were those with an incidence of a disorder smaller than $0.5 \%$ or larger than $95 \%$.

\section{Genotypes}

Animals from commercial herds submitted to Zoetis for genomic testing were genotyped with various versions of low-density chips, with the number of markers ranging from 3,000 to about 35,000. Jersey bulls from Zoetis Research and Development assets were geno- typed with the Zoetis custom medium-density chip with about 70,000 SNP. Raw genotypes were edited following the criteria described in Wiggans et al. (2009) and Vukasinovic et al. (2017). All animals genotyped with lower density chips $(<40,000$ markers) were imputed using the program FImpute (Sargolzaei et al., 2011) to a set of 45,163 markers selected based on their call rates and minor allele frequencies. In addition to the genotypes produced in the Zoetis laboratory, genotypes of 264 Jersey bulls were obtained in silico by inferring from their offspring genotypes using Zoetis proprietary methodology. After editing, a total of 41,271 genotyped animals remained for analysis.

\section{Definition of Jersey Animals}

The pedigree-based breed composition for all animals in the pedigree was determined using the $\mathrm{R}$ package OptiSel (Wellmann, 2018). However, if the animal was genotyped, it was included in the analysis only if it was defined as a Jersey by the CDCB based on the SNP-based breed check (https://redmine.uscdcb.com/ projects/cdcb-customer-service/wiki/CDCB_Genomic _Dictionary). The animal was excluded if the CDCB test classified it as non-Jersey regardless of the pedigree-based breed composition.

\section{Statistical Model}

Each trait was analyzed separately in a univariate analysis. Variance components for the cow wellness traits were estimated using the following threshold animal model with repeated observations:

$$
\boldsymbol{\lambda}=\mathbf{X} \boldsymbol{\beta}+\mathbf{Z}_{h} h+\mathbf{Z}_{a} a+\mathbf{Z}_{p} p+e
$$

Table 1. Characteristics of the data used in the genomic evaluation for Jersey wellness traits

\begin{tabular}{|c|c|c|c|c|c|c|}
\hline Trait $^{1}$ & Time observed & Incidence $(\%)$ & Records (no.) & Animals $^{2}$ (no.) & $\mathrm{G}+\mathrm{P}^{3}$ & Pedigree $^{4}$ \\
\hline METR & Lactation & 2.73 & 248,646 & 135,295 & 3,774 & 280,964 \\
\hline RETP & Lactation & 1.63 & 355,886 & 179,040 & 4,320 & 317,221 \\
\hline KETO & Lactation & 1.62 & 304,700 & 162,331 & 2,904 & 307,897 \\
\hline LAME & Lactation & 8.59 & 607,732 & 279,381 & 6,065 & 428,078 \\
\hline MFV & Lactation & 1.20 & 336,446 & 175,340 & 4.029 & 310,395 \\
\hline
\end{tabular}

${ }^{1}$ MAST $=$ mastitis; METR $=$ metritis; RETP $=$ retained placenta DA $=$ displaced abomasum $; \mathrm{KETO}=$ ketosis $;$ LAME $=$ lameness; MFV $=$ milk fever; RESP = calf respiratory disease; DIAR = calf scours; DEAD = calf livability.

${ }^{2}$ Number of animals with phenotype.

${ }^{3}$ Number of animals with genotype that also had phenotype for each trait.

${ }^{4}$ Number of animals in the final pedigree for each trait. 
where $\boldsymbol{\lambda}$ is the vector of unobserved liabilities to the given disorder; and $\boldsymbol{\beta}$ is the vector of fixed parity effects ( 5 classes: parity $1,2,3,4$, or $\geq 5$ ), with the corresponding incidence matrix $\mathbf{X}$. $h$ is the random herd-yearseason effect, where $h \sim N\left(0, \mathbf{I} \sigma_{h}^{2}\right)$, with the variance $\sigma_{h}^{2}$; 4 seasons were defined within each calving year (winter $=$ December to February; spring = March to May; summer = June to August; and fall = September to November). $a$ is the random animal effect, with $a \sim N\left(0, \mathbf{H} \sigma_{a}^{2}\right)$, where $\sigma_{a}^{2}$ is the additive genetic variance and $\mathbf{H}$ is the pedigree relationship matrix augmented using genotypes. $p$ is the random effect of permanent environment, with $p \sim N\left(0, \mathbf{I} \sigma_{p}^{2}\right)$, where $\sigma_{p}^{2}$ is the permanent environment variance, and $e$ is the residual, where $e \sim N(0, \mathbf{I}) . \mathbf{Z}_{h}, \mathbf{Z}_{a}$, and $\mathbf{Z}_{p}$ are incidence matrices corresponding to the random effects of herd $\times$ year $\times$ season, animal, and permanent environment, respectively; and $\mathbf{I}$ is the identity matrix.

Variance components for the calf wellness traits were estimated using the model

$$
\boldsymbol{\lambda}=\mathbf{X} \boldsymbol{\beta}+\mathbf{Z}_{h} h+\mathbf{Z}_{a} a+e,
$$

where $\boldsymbol{\lambda}$ is the vector of the animals' unobserved liabilities to the given disorder; $\boldsymbol{\beta}$ is the vector of fixed effects of year $\times$ calving season $\times$ region combination: years 1996 to 2017 were considered; 4 calving seasons were defined within each year (winter $=$ December to February; spring = March to May; summer = June to August; and fall $=$ September to November); and 5 geographical regions based on climate were defined as in VanRaden et al. (2004) based on the first 2 digits of the herd code, which represent the state where the herd is located. $h$ is the random herd-year effect, where $h \sim N\left(0, \mathbf{I} \sigma_{h}^{2}\right)$, with the variance $\sigma_{h}^{2} ; a$ is the random animal effect, with $a \sim N\left(0, \mathbf{H} \sigma_{a}^{2}\right)$, where $\sigma_{a}^{2}$ is the additive genetic variance and $\mathbf{H}$ is the pedigree relationship matrix augmented using genotypes. $\mathbf{X}, \mathbf{Z}_{h}$, and $\mathbf{Z}_{a}$ are the incidence matrices corresponding to the fixed effects in $\boldsymbol{\beta}$ and the random effects of herd $\times$ year and animal, respectively; and $\mathbf{I}$ is the identity matrix.

The THRGIBBS1F90 program version 2.108 from the BLUPF90 family (Misztal et al., 2002) was used to estimate variance components for the cow wellness traits. Variance components for the calf wellness traits were instead estimated using ASReml version 4.1 (Gilmour et al., 2015). The analysis was carried out using generalized linear models with binomial distribution and a link function of LOGIT where the residual variance on the underlying scale equals $1 / 3 \pi^{2}$. The program
THRGIBBSF90 was not used to estimate variance components for calf traits because in a previous study (Gonzalez-Peña et al., 2019) it did not converge for all traits, probably due to a substantial number of levels of the fixed effect of year $\times$ season $\times$ region (Misztal, 2005).

All variance components were estimated without genomic information, using all the phenotype available, and considering up to the depth of 20 generations or the maximum number of generations available for each animal in the pedigree. The average number of generations for animals with phenotypes or genotypes was 5.7 and 2.4 for the paternal and maternal sides, respectively. The original variance component estimates for the calf traits were divided by 3.29 to accommodate the requirements of the BLUPF90 programs for the error variance $=1$.

\section{Genomic Evaluation}

Genetic evaluation was performed using the programs from the BLUPF90 family (Misztal et al., 2014). A univariate threshold model based on ssGBLUP was applied to all traits. In ssGBLUP, the inverse of the traditional pedigree relationship matrix, $\mathbf{A}^{-1}$, is replaced by the inverse of the $\mathbf{H}$ matrix that combines the pedigree $(\mathbf{A})$ and the genomic relationship matrix G (Legarra et al., 2009; Aguilar et al., 2010):

$$
\mathbf{H}^{-1}=\mathbf{A}^{-1}+\left[\begin{array}{cc}
0 & 0 \\
0 & \mathbf{G}^{-1}-\mathbf{A}_{22}^{-1}
\end{array}\right],
$$

where $\mathbf{A}^{-1}$ is an inverse of the pedigree relationship matrix; $\mathbf{G}^{-1}$ is an inverse of the genomic relationship matrix; and $\mathbf{A}_{22}^{-1}$ is an inverse of the pedigree relationship matrix for genotyped animals only. The program CBLUP90IOD2 version 3.34 (Misztal et al., 2014) was used to obtain genomic breeding values by iteration on data using preconditioned conjugate gradient. The genomic matrix conditioning parameters tau and omega were set to 1.0. The number of preconditioned conjugate gradient rounds (internal iterations) was set to 200. Inbreeding was considered when constructing the pedigree relationship matrix. The reliabilities of estimated breeding values were obtained with the program ACCF90GS version 2.49 (Misztal et al., 2014), which approximates reliabilities using contributions from genotypes, phenotypes, and pedigree. To reduce computational requirements, the contribution from genotypes is replaced by the value of the diagonal of the $\mathbf{G}$ matrix, $g_{i i}$. The following formula was used to approxi- 
mate reliabilities for genotyped animals (Daniela Lourenco, University of Georgia, Athens, personal communication, 2016):

$$
d_{i}^{g}=\alpha \times\left[\left(\overline{R E L}+g_{i i}\right)+\overline{R e l-R e l_{P A}}\right],
$$

where $d_{i}^{g}$ is the reliability of (genomic) EBV for animal $i ; \alpha$ is the ratio of error variance to additive genetic variance; $g_{i i}$ is the diagonal element of the genomic relationship matrix pertinent to animal $i ; \overline{R E L}$ is the average base change in genomic reliability; and $\overline{R e l-R e l_{P A}}$ is the contribution from phenotypes of genotyped animals.

\section{Expression of EBV}

For each trait, the solutions from the CBLUP90IOD program (raw EBV) were transformed into probabilities of exceeding the threshold value. The threshold represents the transition value between the 2 stages of the categorical variable (healthy $=0$, sick $=1$ ). Threshold values for all traits were calculated from the current data. For each animal solution, we calculated the probability that a standard normal variable with a mean equal to that solution and a variance of 1 exceeds the threshold. The probabilities were then multiplied by 100 (to represent percentage) and divided by 2 (to obtain PTA). The resulting PTA were expressed as the deviation of the average PTA of all animals (genotyped or not) born in 2010 with a phenotypic record for that trait.

The resulting PTA, or genomic PTA (gPTA) for genotyped animals, may be interpreted as the difference of the individual animal's risk of getting a disorder from the average (base) risk. Higher values indicate a higher risk of disorder. For example, an animal with a gPTA of -2.0 has $2 \%$ lower risk, whereas an animal with a gPTA of +2.0 has a $2 \%$ higher risk of getting a disorder compared with the base animal.

\section{Correlations of Jersey Wellness gPTA with gPTA for Traits in the US National Evaluation}

To check the associations among the wellness traits and with the gPTA for the traits in the US national genetic evaluation for Jerseys, product-moment (Pearson) correlations were calculated for all animals with the reliability of PTA above 0 regardless of whether the animals were genotyped. The genetic correlations between the traits were not estimated because the software used for analysis (CBLUP90IOD) does not support multiple threshold traits. The approximation of genetic correlations using the method of Calo et al. (1973) was not performed.

\section{RESULTS AND DISCUSSION}

\section{Data Characteristics}

Table 1 shows the number of phenotypic records, incidence, number of animals with both genotypes and phenotypes, and total number of animals in the pedigree for each of the analyzed traits. The number of records for cow wellness traits ranged from 216,166 for DA to 628,958 for MAST. Such big differences in number of records available for individual traits were caused by large variations in recording among the farms. Although most herds recorded MAST and LAME, a relatively small proportion of herds recorded other traits in Jerseys. The average incidence of MAST was somewhat higher in Jerseys than in Holsteins (27.7\% vs. 25\%; Vukasinovic et al., 2017) and higher than that found by Jensen et al. (2019) in a smaller set of Jersey data. Previous studies found that mastitis incidence varies substantially among countries, herds, and breeds, ranging from $11 \%$ up to $40 \%$ (Heringstad et al., 2000; Olde Riekerink et al., 2008; van den Borne et al., 2010; Santman-Berends et al., 2015; Jensen et al., 2019). The rest of the traits had lower average incidence than Holsteins, consistent with the findings of Olson et al. (2011). A similar trend was found in Australia by Abdelsayed et al. (2017) except for metabolic diseases that included milk fever, grass tetany, and ketosis (1.7\% for Jersey vs. $0.92 \%$ for Holstein). Compared with the results previously published by Parker Gaddis et al. (2018) for Jersey, the incidence of KETO was lower in our study (2.8\% vs. $1.62 \%$, respectively), probably due to differences in data used in the analysis. Milk fever showed the same average incidence as Holsteins (unpublished results by Zoetis Genetics, 2018). However, some studies found Jerseys to be more susceptible to MFV than other breeds (Lean et al., 2006; Roche and Berry, 2006; Saborío-Montero et al., 2017). Relative to Holsteins, the Jersey breed was 2.37 and 4.96 times more susceptible to MFV in a metaanalysis study (Lean et al., 2006) and in grazing systems (Roche and Berry, 2006), respectively. In a Costa Rica grazing system, the Jersey breed was 3.04 times more susceptible than Brown Swiss to MFV (SaboríoMontero et al., 2017). The incidence of MFV found in our study was lower than the national average of more than $7 \%$ (Goff and Horst, 1997) and lower than the median incidence of $2.82 \%$ reported in 12 large studies conducted in various North American and European countries (Pryce et al., 2016). 
The number of records for calf wellness traits ranged from 186,505 records for DIAR to 380,429 records for DEAD. The incidence of RESP was lower in Jerseys than in Holsteins (13.6\% vs. $21 \%$ ), but the incidence of DIAR was much higher in Jerseys than in Holsteins (>36\% vs. 26\%; Gonzalez-Peña et al., 2019). The higher incidence of DIAR may also be attributed to recording loose manure in otherwise healthy animals caused by the high-fat, high-protein diet recommended for Jersey calves (Pedraza and Vigil, 2014). Relative to Holstein calves (4.7\%; Gonzalez-Peña et al., 2019), Jersey calves had a higher mortality rate $(5.9 \%)$. The mortality of dairy calves reported in Europe was in the range of 4 to 7\% (Agerholm et al., 1993; Svensson and Liberg, 2006; Gulliksen et al., 2009). Weigel and Barlass (2003) found that purebred Jersey calves had the highest calf mortality score in a producer survey, suggesting that calves with a high percentage of Jersey genes had an undesirable direct effect on survival. Supporting this, Thomsen and Houe (2006) and Pinedo et al. (2014) found a higher death rate for Jersey cows relative to Holstein cows.

\section{Variance Components and Heritabilities}

Table 2 shows estimates for genetic, permanent environment (cow wellness traits), herd $\times$ year $\times$ season (or herd $\times$ year for calf wellness traits), and residual variance and heritabilities used in genetic evaluation. Because a threshold model was used, the heritabilities are on the underlying (liability) scale.
The estimated heritabilities for cow wellness traits ranged from 0.06 for DA to 0.12 for LAME and were somewhat higher than the heritabilities for the same traits estimated with the same model for Holsteins (Vukasinovic et al., 2017). Estimated heritabilities for all traits were noticeably higher than those for health traits in the Holstein population reported by CDCB (2018b), which is most likely due to the differences between the models used for estimation of variance components. Likewise, in Austrian Fleckvieh dualpurpose cows, the mastitis heritabilities under probit and logit models were 0.06 and 0.08 , respectively, and for linear sire and linear animal models the estimates were lower (0.02; Koeck et al., 2010). The heritabilities estimated with a threshold model are on the underlying scale, capturing more (genetic) variability than those on the observed scale estimated using a linear model. Moreover, heritabilities on the underlying scale are independent of the differences in disease incidence among herds, whereas heritabilities on the observed scale can vary from one herd to another or change with addition of new herds, depending on the incidence of a disorder within individual herds (Misztal, 2017). The estimated heritability for KETO in this study was slightly higher than that found by Parker Gaddis et al. (2018) in a similar Jersey population using a threshold model (0.10 vs. 0.08$)$. Heritability of KETO estimated with a threshold model in Holstein Friesians and Norwegian Reds ranged from 0.02 to 0.16 (Pryce et al., 2016). Similarly, MFV was in the range of 0.07 to 0.18 reported by Pryce et al. (2016). Meanwhile, DA was lower

Table 2. Estimated variance components ${ }^{1}$ for Jersey wellness traits

\begin{tabular}{lcccc}
\hline Trait $^{2}$ & $\operatorname{Var}(\mathrm{g})$ & $\operatorname{Var}(\mathrm{pe})$ & $\operatorname{Var}($ hys $) / \operatorname{Var}($ hy $)$ & $\mathrm{h}^{2}$ \\
\hline MAST & 0.272 & 0.118 & 1.555 & 0.092 \\
METR & 0.158 & 0.025 & 0.168 & 0.117 \\
RETP & 0.129 & 0.050 & 0.144 & 0.097 \\
DA & 0.088 & 0.065 & 0.285 & 0.061 \\
KETO & 0.162 & 0.068 & 0.404 & 0.099 \\
LAME & 0.235 & 0.159 & 0.566 & 0.120 \\
MFV & 0.152 & -251 & 0.280 & 0.090 \\
RESP $^{3}$ & 0.103 & - & 0.780 & 0.055 \\
DIAR $^{3}$ & 0.146 & - & 0.582 & 0.084 \\
DEAD $^{3}$ & 0.147 & & 0.282 & 0.103
\end{tabular}

${ }^{1} \operatorname{Var}(\mathrm{g})=$ additive genetic variance; $\operatorname{Var}(\mathrm{pe})=$ permanent environment variance; $\operatorname{Var}($ hys $)=$ herd-year-season variance; $\operatorname{Var}($ hy $)=$ herd-year variance. The residual variance $\operatorname{Var}(\mathrm{e})$ was equal to 1 for all traits. $\mathrm{h}^{2}=$ heri- $^{2}$ tability.

${ }^{2} \mathrm{MAST}=$ mastitis; $\mathrm{METR}=$ metritis; $\mathrm{RETP}=$ retained placenta $; \mathrm{DA}=$ displaced abomasum $; \mathrm{KETO}=$ ketosis; LAME = lameness; MFV = milk fever; RESP = calf respiratory disease; DIAR = calf scours; DEAD $=$ calf livability.

${ }^{3}$ For calf wellness traits, the original variance components obtained with the ASReml software (Gilmour et al., 2015) were divided by 3.29 to accommodate the requirements for $\operatorname{Var}(\mathrm{e})$ in the BLUPF90 programs (Misztal et al., 2014). 
Table 3. Mean, standard deviation, minimum, and maximum of estimated genomic PTA for Jersey wellness traits for all genotyped animals $(\mathrm{n}=41,271)$

\begin{tabular}{lrrrr}
\hline Trait $^{1}$ & Mean & SD & Minimum & Maximum \\
\hline MAST & 0.64 & 4.52 & -12.8 & 20.3 \\
METR & 0.03 & 1.79 & -4.9 & 9.9 \\
RETP & -0.54 & 1.26 & -4.8 & 8.0 \\
DA & 0.12 & 0.88 & -2.6 & 5.7 \\
KETO & 1.18 & 1.71 & -3.8 & 15.0 \\
LAME & -0.53 & 3.06 & -9.5 & 14.9 \\
MFV & -0.34 & 0.94 & -3.5 & 8.6 \\
RESP & -0.92 & 2.23 & -7.8 & 12.8 \\
DIAR & -1.42 & 5.37 & -17.9 & 20.2 \\
DEAD & -1.59 & 2.11 & -7.4 & 8.5 \\
\hline
\end{tabular}

${ }^{1}$ MAST $=$ mastitis $;$ METR $=$ metritis $;$ RETP $=$ retained placenta $;$ DA $=$ displaced abomasum; KETO = ketosis; LAME = lameness; MFV $=$ milk fever; RESP $=$ calf respiratory disease; DIAR $=$ calf scours; $\mathrm{DEAD}=$ calf livability

than the range established by the threshold model and more similar to the linear estimates (Pryce et al., 2016).

The estimated heritabilities for calf wellness traits were $0.06,0.08$, and 0.10 for RESP, DIAR, and $\mathrm{DEAD}$, respectively, and were somewhat higher than the heritabilities for the same traits in Holstein calves (Gonzalez-Peña et al., 2019). Generally, the estimated heritabilities for the calf traits were consistent with or just a little higher than previously reported results obtained with a similar model in other dairy calf populations (Henderson et al., 2011; McCorquodale et al., 2013). However, the heritability for DEAD obtained in the present study was much higher than the heritability for heifer livability $\left(\mathrm{h}^{2}=0.005\right)$ on the observed scale reported by VanRaden et al. (2016), who used a much larger data set in a multibreed analysis. Higher heritabilities in our Jersey data may be due to the specific population structure or the fact that most of the animals were from California and therefore had reduced environmental variance (Browning and Browning, 2011).

\section{Genomic Predictions}

Tables 3 and 4 show descriptive statistics for gPTA and reliabilities, respectively, for all genotyped animals in the analysis. The average values, standard deviations, and extreme values of gPTA were comparable with those for wellness traits in Holstein cows (Vukasinovic et al., 2017) and calves (Gonzalez-Peña et al., 2019). The standard deviations and range of gPTA reflect the incidence of the disorders and were the smallest for DA (the trait with only $0.6 \%$ incidence) and the largest for DIAR, which affected more than $36 \%$ animals in our data. Broader range of gPTA is preferable because it enables better segregation of animals of different genetic merit for wellness traits.

Reliabilities (Table 4) averaged from 0.32 for DA to 0.51 for MAST and DEAD. The reliabilities reflected both the amount of data and the heritabilities of the traits. More data and higher heritabilities resulted in higher average reliabilities in animals under selection. Overall, the average reliabilities were smaller than in Holsteins due to the much smaller amount of data, both phenotypes and genotypes, available for Jerseys and possibly weaker connections between the animals in the pedigree. The average reliabilities are expected to increase as the amount of data grows.

A small number of genotyped animals had reliabilities equal to 0 , ranging from 2 to 30 for MAST and DA, respectively. Zero reliabilities for genotyped animals are not expected unless an animal belongs to a different breed or is poorly connected to the population and has an extreme value of the diagonal of the genomic relationship matrix. Most of the animals with 0 reliabilities

Table 4. Means, standard deviations, minimum, and maximum of genomic reliabilities for wellness traits for all genotyped animals $(\mathrm{n}=41,271)$ and the number of animals with reliability equal to 0

\begin{tabular}{|c|c|c|c|c|c|}
\hline Trait $^{1}$ & Mean & SD & Minimum & Maximum & $\begin{array}{l}\text { Animals with } \\
\text { reliability }=0 \text { (no.) }\end{array}$ \\
\hline MAST & 0.505 & 0.071 & 0 & 0.997 & 2 \\
\hline METR & 0.412 & 0.071 & 0 & 0.990 & 10 \\
\hline RETP & 0.405 & 0.071 & 0 & 0.991 & 10 \\
\hline DA & 0.321 & 0.074 & 0 & 0.971 & 30 \\
\hline KETO & 0.367 & 0.079 & 0 & 0.992 & 12 \\
\hline LAME & 0.467 & 0.074 & 0 & 0.997 & 3 \\
\hline MFV & 0.393 & 0.073 & 0 & 0.991 & 13 \\
\hline RESP & 0.428 & 0.065 & 0 & 0.988 & 9 \\
\hline DIAR & 0.447 & 0.067 & 0 & 0.990 & 8 \\
\hline DEAD & 0.505 & 0.059 & 0 & 0.994 & 3 \\
\hline
\end{tabular}

${ }^{1}$ MAST $=$ mastitis; METR $=$ metritis; RETP $=$ retained placenta $; \mathrm{DA}=$ displaced abomasum; KETO = ketosis; LAME = lameness; MFV = milk fever; RESP = calf respiratory disease; DIAR = calf scours; DEAD $=$ calf livability. 
originally failed the CDCB breed check and passed only after being regenotyped with a medium-density chip, which has a less strict threshold. Although these animals were defined as Jersey at CDCB, their genome was crossbred and therefore not well connected to the rest of the animals in the data. Another category of animals with 0 reliabilities were foreign Jersey animals or their offspring without genotyped ancestors or relatives in our data. Although the same genotypes were used for all traits, the highest number of animals with 0 reliabilities was obtained for DA. In addition to the diagonal of genomic relationship matrix, the approximation formula for reliability is based on the variance ratio and contribution from the parents. Thus, traits with low heritability and low incidence, such as DA, will have more 0 reliabilities for poorly connected animals.

Tables 5 and 6 show descriptive statistics for gPTA and reliabilities, respectively, for cow and calf wellness traits for young genotyped Jersey animals without phenotype or progeny, for animals with 1 phenotypic record, and for animals with 2 or more lactations. The means, standard deviations, and extremes of gPTA for young animals without phenotypes showed values similar to those for genotyped animals with records. However, for most traits, the average gPTA were slightly higher than for animals with phenotypes, possibly indicating a decreasing trend in wellness traits in Jerseys, which could be inferred from the declining trend in livability of Jersey animals in recent years (CDCB, 2019a). The average reliabilities for young animals (Table 6) were about $8 \%$ lower than the reliabilities for animals with 1 phenotypic record; reliabilities for cow wellness traits for young genotyped animals without phenotypes were on average $12 \%$ lower than reliabilities of animals with 2 or more lactation records. As expected, having at least 1 phenotypic record (in addition to genotype and pedigree) increased reliabilities, but the contribution of phenotypes to the reliabilities of well-connected genotyped animals is proportionally very small. However, the importance of phenotypic records in genomic evaluation using ssGBLUP should not be underestimated because phenotypic data from daughters influence reliabilities of PTA of their sires, which translates into reliabilities of their young genotyped offspring (Figure 1).

\section{Correlations with Other Traits}

The product-moment correlations among the PTA for cow and calf wellness traits are presented in Table 7. These correlations were calculated for all animals with reliabilities of PTA greater than 0 for any pair of traits, therefore including animals with genotypes, phenotypes, or both as well as ancestors of animals in the analysis. (In addition, correlations were calculated

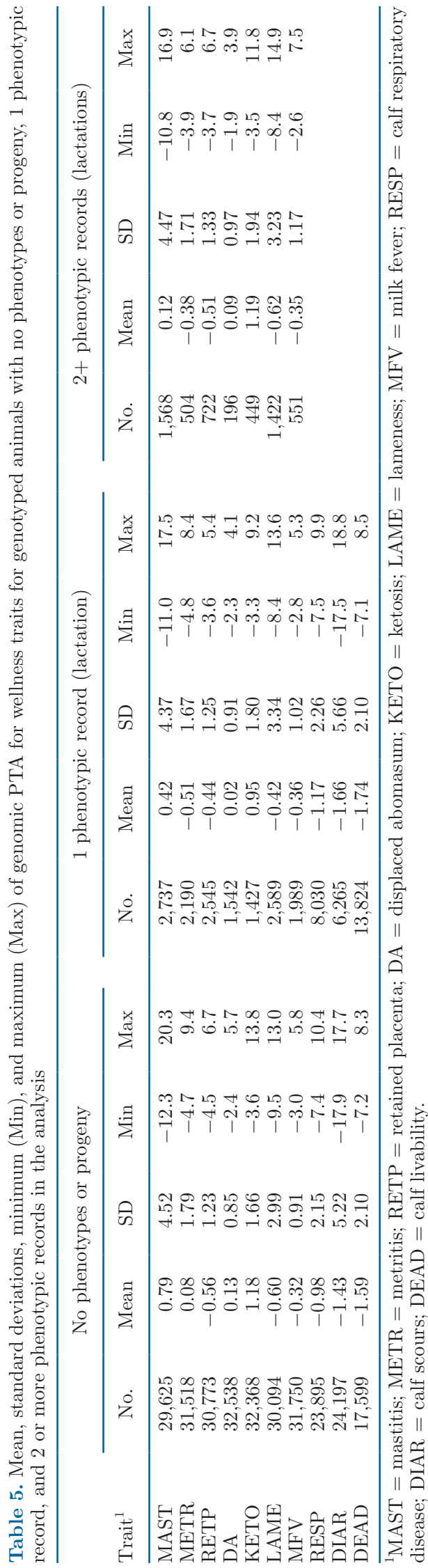




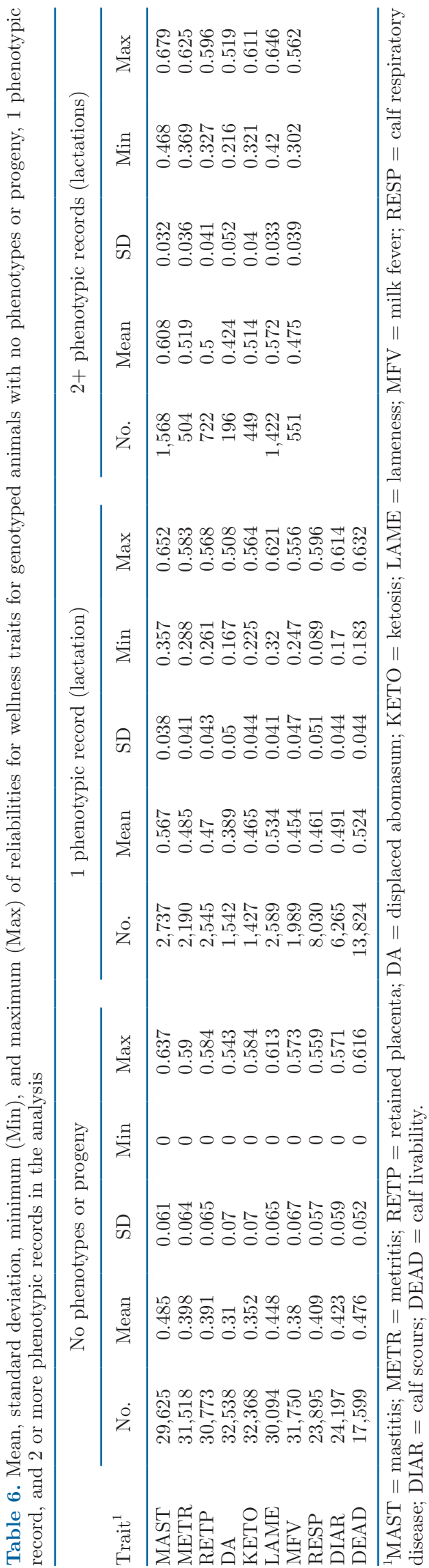

for all animals with reliability $\geq 0.3$, which resulted in very similar values.) All but 1 correlation among the cow trait PTA were positive, indicating that when a cow has one health disorder, she may be more susceptible to other disorders (Pryce et al., 2016). The highest correlation was found between KETO and DA (correlation $=0.453)$, consistent with the results reported for Holsteins (Parker Gaddis et al., 2014). During the transition period in dairy cows, impaired energy metabolism could increase levels of blood ketone bodies. According to Duffield et al. (2002), animals with $\mathrm{BHB}$ concentration in blood greater than 1,200 $\mu \mathrm{mol} / \mathrm{L}$ were 2.6 and 3.35 times more likely to develop DA and METR, respectively. Displaced abomasum also showed moderate positive correlation (0.385) with MVF. All other correlations were below 0.3 in magnitude. The only negative correlation was found between METR and LAME, but it was negligibly low. In a study of wellness traits in Holsteins, Pearson correlations had the same direction but significantly lower magnitude than approximated genetic correlations (Vukasinovic et al., 2017). Similar data (Vukasinovic et al., 2017; Gonzalez-Peña et al., 2019) have shown that Calo's correlation does not provide additional insights into genetic relationships among the traits.

Positive correlations ranging from 0.23 to 0.29 were obtained among the calf trait PTA. Similar but twice as high correlations were previously reported among calf wellness traits in Holstein calves (Gonzalez-Peña et al., 2019). As indicated by Mahmoud et al. (2017), the correlations between PTA were likely underestimated because the reliabilities of PTA were $<1$ and the PTA were not adjusted for reliabilities as in the approximation method by Calo et al. (1973) because the PTA were not obtained on the independent groups of animals. The actual genetic correlations among the traits were likely much higher in magnitude than the product-moment correlations presented here.

The correlations of PTA among cow and calf wellness traits were low, ranging from -0.118 (between DIAR and DA) to 0.140 (between RESP and RETP). There were no clear indications that increased risk of calfhood problems and mortality leads to increased incidence of health problems in adult cows. Comparable results were obtained between calf and cow wellness traits in Holsteins (Gonzalez-Peña et al., 2019). Similarly, Mahmoud et al. (2017) concluded that calf diseases were poor predictors of a cow's health in German Holstein cows.

Table 8 shows correlations between cow and calf wellness traits with the most commonly reported production, fertility, type, and longevity traits in the US national genetic evaluation. Because the PTA for those traits were supplied to us by $\mathrm{CDCB}$, these cor- 
Table 7. Product-moment (Pearson) correlations among Jersey wellness traits

\begin{tabular}{|c|c|c|c|c|c|c|c|c|c|c|}
\hline Trait $^{1}$ & MAST & METR & RETP & DA & KETO & LAME & MFV & RESP & DIAR & DEAD \\
\hline METR & & & 0.188 & 0.027 & 0.133 & -0.020 & 0.124 & -0.020 & 0.043 & 0.078 \\
\hline RETP & & & & 0.039 & 0.263 & 0.033 & 0.068 & 0.140 & 0.089 & 0.046 \\
\hline KETO & & & & & & 0.075 & 0.294 & -0.064 & -0.039 & -0.072 \\
\hline LAME & & & & & & & 0.013 & 0.027 & 0.090 & 0.048 \\
\hline MFV & & & & & & & & 0.003 & 0.025 & -0.090 \\
\hline
\end{tabular}

${ }^{1} \mathrm{MAST}=$ mastitis $;$ METR $=$ metritis $; \mathrm{RETP}=$ retained placenta $; \mathrm{DA}=$ displaced abomasum $; \mathrm{KETO}=$ ketosis $; \mathrm{LAME}=$ lameness $; \mathrm{MFV}=$ milk fever; RESP $=$ calf respiratory disease $;$ DIAR $=$ calf scours; DEAD = calf livability.

relations were calculated based mostly on the genomic predictions of genotyped females, the majority of which did not have phenotypic data or offspring. Although most of the correlations were low and not exceeding the value of 0.4 in magnitude, some directions could be identified. The highest positive correlations were obtained between MAST and milk, fat, and protein yield. Positive correlations between MAST and yield traits were also reported by Parker Gaddis et al. (2014) and Vukasinovic et al. (2017) in Holsteins. Both studies reported negative correlations with net merit $(\$ \mathbf{N M})$; however, in the present study, MAST was positively associated with \$NM. Similarly, METR and MFV had positive correlations with yield traits and $\$ \mathrm{NM}$. Unfavorable correlations between MFV and milk yield were reported in dairy cattle (Kadarmideen et al., 2000; Fleischer et al., 2001; Saborío-Montero et al., 2017), which could potentially be explained by increased Ca demands of high-yielding cows because of secretion of Ca into colostrum (Liesegang et al., 1998, 2000). These correlations may indicate that Jersey cows with a higher potential for production are at higher risk of developing health problems such as MAST, METR, and MFV. Positive correlations of MAST, METR, and

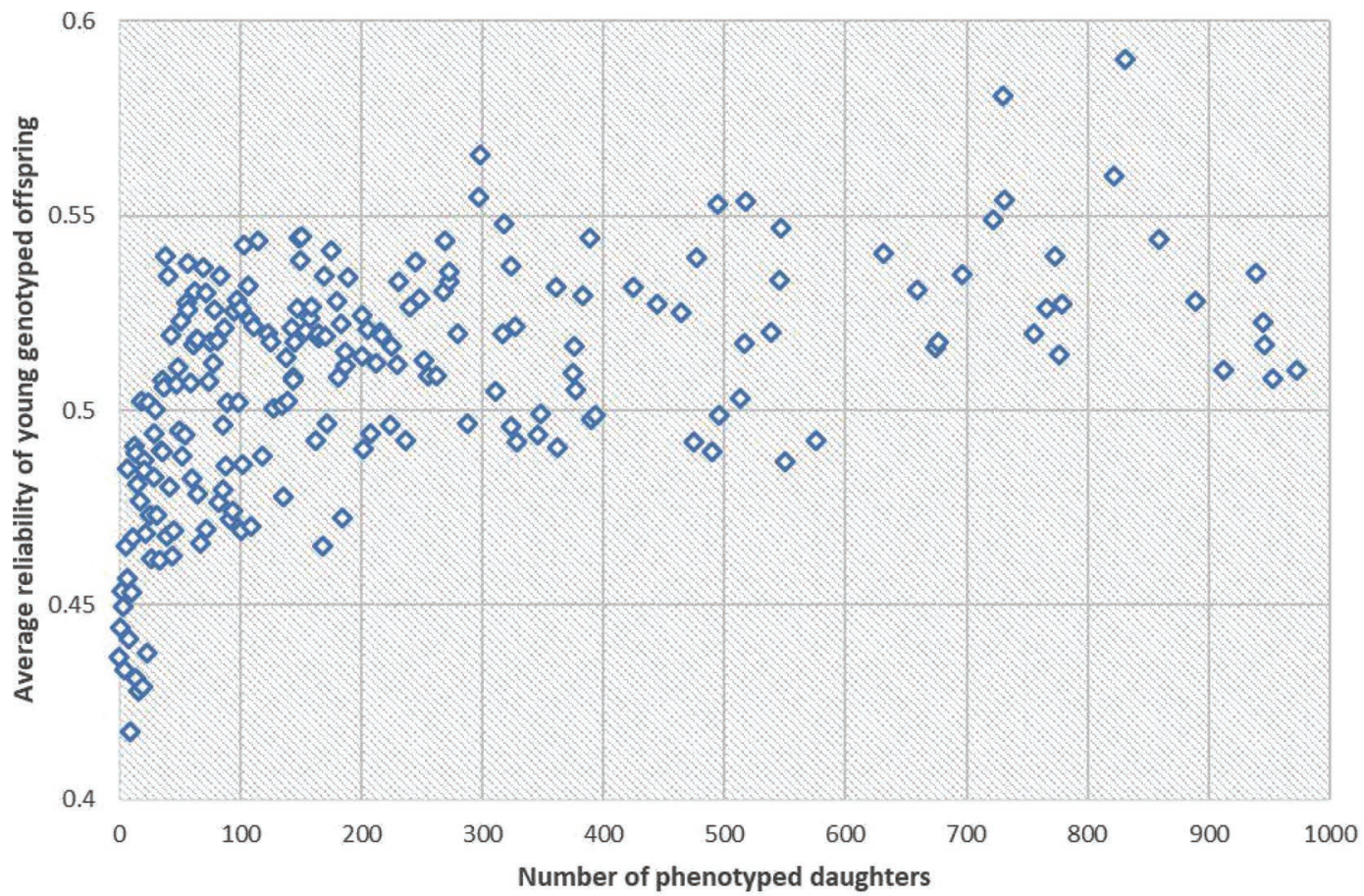

Figure 1. Relationship between number of phenotyped daughters of a sire and the reliability of genomic predictions for mastitis of his young genotyped offspring. The graph shows the data on a subset of 209 sires having 0 to 973 offspring with mastitis phenotypes and averaging 129 offspring per sire with only genotypes. Increasing the number of daughters with phenotypes leads to higher reliabilities of genomic PTA of the sire's genotyped offspring without own phenotype or progeny. 
Table 8. Product-moment (Pearson) correlations of Jersey wellness traits with the traits in the US national genetic evaluation provided by the Council on Dairy Cattle Breeding*

\begin{tabular}{|c|c|c|c|c|c|c|c|c|c|c|c|c|}
\hline Trait $^{1}$ & $\$ N M$ & Milk & Fat & Prot & SCS & DPR & $\mathrm{PL}$ & CCR & HCR & PTAT & LIV & GL \\
\hline METR & 0.116 & 0.023 & 0.217 & 0.124 & 0.076 & -0.228 & -0.031 & -0.271 & -0.176 & 0.185 & -0.125 & 0.046 \\
\hline KETO & -0.094 & 0.038 & 0.010 & -0.027 & 0.021 & -0.044 & -0.168 & -0.058 & -0.167 & 0.000 & -0.241 & -0.044 \\
\hline LAME & -0.011 & -0.028 & 0.112 & 0.032 & 0.056 & -0.099 & -0.158 & -0.060 & 0.019 & -0.114 & -0.114 & 0.019 \\
\hline MFV & 0.053 & 0.128 & 0.126 & 0.143 & 0.025 & -0.065 & -0.103 & -0.045 & -0.080 & 0.064 & -0.319 & 0.109 \\
\hline DEAD & -0.122 & -0.157 & -0.008 & -0.098 & 0.142 & -0.205 & -0.159 & -0.185 & -0.098 & -0.011 & -0.050 & -0.022 \\
\hline
\end{tabular}

${ }^{1}$ MAST $=$ mastitis; METR $=$ metritis; RETP $=$ retained placenta; DA = displaced abomasum; KETO = ketosis; LAME $=$ lameness; $\mathrm{MFV}=$ milk fever; RESP $=$ calf respiratory disease DIAR = calf scours; DEAD = calf livability; $\$ N M=$ net merit; Milk = milk yield; Fat $=$ fat yield; Prot $=$ protein yield $; \mathrm{DPR}=$ daughter pregnancy rate; $\mathrm{PL}=$ productive life; $\mathrm{CCR}=$ cow conception rate; $\mathrm{HCR}=$ heifer conception rate; $\mathrm{PTAT}$ $=$ PTA type; $\mathrm{LIV}=$ cow livability; GL = gestation length.

$* P<0.05$.

MVF with $\$ N M$ in Jerseys, which were not consistent with the results from Holsteins, may be attributed to differences in trait weighting and genetic parameters between Jersey and Holstein breeds (VanRaden et al., 2018).

The correlation between MAST and SCS was 0.14 and was lower than the correlation between MAST and SCS found in Holsteins (0.46; Vukasinovic et al., 2017). Similarly, Jensen et al. (2019) found lower correlations between MAST and SCS in Jerseys than in Holsteins (0.41 vs. 0.70). Estimates of genetic correlations between MAST and SCS in the literature vary widely from around 0 up to 0.8 (Philipsson et al., 1995; Rainard et al., 2018; Jensen et al., 2019).

All cow and calf traits were positively correlated with SCS and negatively correlated with productive life, DEAD, daughter pregnancy rate (except for DA, correlation $=0.051$ ), cow conception rate (except for $\mathrm{DA}$, correlation $=0.006)$, and heifer conception rate (except for LAME, correlation $=0.019$ ). On the other hand, calf wellness traits had negative correlations with $\$ N M$ and all yield, fertility, and longevity traits and positive correlations with SCS. Cow and calf wellness traits were weakly or not at all correlated with PTA type and gestation length, except for DIAR, which was positively but lowly correlated with gestation length. Similar low correlations between calf wellness traits and traits in the US National Genetic Evaluation were found in Holsteins (Gonzalez-Peña et al., 2019). The negative effect of diseases on the early life of animals had been reported in dairy cattle (Rossini, 2004; Henderson et al., 2011; Dunn et al., 2018). This effect is probably underestimated due to removal of animals before reaching first lactation, which creates a survival bias (Stanton et al., 2012).

\section{CONCLUSIONS}

Genetic and genomic evaluation for cow and calf wellness traits in Jersey cattle based on producer-recorded data has been developed. The estimated heritabilities of the traits were comparable with estimates in the literature. The obtained gPTA and reliabilities show that selection of Jersey animals for wellness traits may be successful and could contribute to the genetic progress. Genomic predictions for cow and calf wellness provide relevant information to dairy producers who seek to continue to improve health and profitability of the Jersey dairy cattle. The wellness traits showed low to moderate correlations with other traits in genetic evaluation, indicating that they would provide additional information if included in selection indices and enable more accurate selection of most profitable animals in dairy herds.

\section{ACKNOWLEDGMENTS}

This research was conducted as a part of the authors' employment with Zoetis LLC.

\section{REFERENCES}

Abdelsayed, M., M. Haile-Mariam, and J. E. Pryce. 2017. Genetic parameters for health traits using data collected from genomic information nucleus herds. J. Dairy Sci. 100:9643-9655. https:// doi.org/10.3168/jds.2017-12960.

Agerholm, J. S., A. Basse, H. V. Krogh, K. Christensen, and L. Rønsholt. 1993. Abortion and calf mortality in Danish cattle herds. Acta Vet. Scand. 34:371-377.

Aguilar, I., I. Misztal, D. L. Johnson, A. Legarra, S. Tsuruta, and T. J. Lawlor. 2010. Hot topic: A unified approach to utilize phenotypic, full pedigree, and genomic information for genetic evaluation of Holstein final score. J. Dairy Sci. 93:743-752. https://doi.org/10 $.3168 /$ jds.2009-2730. 
Bach, A. 2011. Associations between several aspects of heifer development and dairy cow survivability to second lactation. J. Dairy Sci. 94:1052-1057. https://doi.org/10.3168/jds.2010-3633.

Ballou, M. A. 2012. Immune responses of Holstein and Jersey calves during the preweaning and immediate postweaned periods when fed varying planes of milk replacer. J. Dairy Sci. 95:7319-7330. https://doi.org/10.3168/jds.2012-5970.

Beavers, L., and B. Van Doormaal. 2018. Genetic selection for improved hoof health is now possible! Accessed Mar. 12, 2019. https:/ /www.cdn.ca/images/uploaded/file/Hoof\%20Health\%20Index\%20 Article\%20-\%20November\%202018(1).pdf.

Boulton, A. C., J. Rushton, and D. C. Wathes. 2017. An empirical analysis of the cost of rearing dairy heifers from birth to first calving and the time taken to repay these costs. Animal 11:1372-1380. https://doi.org/10.1017/S1751731117000064.

Browning, S. R., and B. L. Browning. 2011. Population structure can inflate SNP-based heritability estimates. Am. J. Hum. Genet. 89:191-193. https://doi.org/10.1016/j.ajhg.2011.05.025.

Calo, L. L., R. E. McDowell, L. D. Van Vleck, and P. D. Miller. 1973. Genetic aspects of beef production among Holstein-Friesians pedigree selected for milk production. J. Anim. Sci. 37:676-682. https: //doi.org/10.2527/jas1973.373676x.

Capper, J. L., and R. A. Cady. 2012. A comparison of the environmental impact of Jersey compared with Holstein milk for cheese production. J. Dairy Sci. 95:165-176. https://doi.org/10.3168/jds .2011-4360.

Cha, E., J. Hertl, D. Bar, and Y. Gröhn. 2010. The cost of different types of lameness in dairy cows calculated by dynamic programming. Prev. Vet. Med. 97:1-8. https://doi.org/10.1016/j .prevetmed.2010.07.011.

Council on Dairy Cattle Breeding. 2018a. Council on Dairy Cattle Breeding activity report Oct 17/Sep 18. Accessed Jan. 3, 2019. https://www.uscdcb.com/wp-content/uploads/2018/10/CDCB _Report_2018_final_web_REV2.pdf.

Council on Dairy Cattle Breeding. 2018b. New genetic evaluations for health traits. Frequently asked questions. March 2018 (update). Accessed Mar. 14, 2019. https://www.uscdcb.com/wp-content/ uploads/2017/09/CDCB-Health-Traits-FAQs-10_2017.pdf.

Council on Dairy Cattle Breeding. 2019a. Genetic and phenotypic trend. Accessed Mar. 12, 2019. https://queries.uscdcb.com/eval/ summary/trend.cfm?R_Menu=JE.v\#chart.

Council on Dairy Cattle Breeding. 2019b. Genotypes included in evaluations by breed, chip density, presence of phenotypes (old vs. young), and evaluation year-month (cumulative). Accessed Jan. 3, 2019. https://queries.uscdcb.com/Genotype/cur_density.html.

Duffield, T., R. Bagg, L. DesCoteaux, E. Bouchard, M. Brodeur, D. DuTremblay, G. Keefe, S. LeBlanc, and P. Dick. 2002. Prepartum monensin for the reduction of energy associated disease in postpartum dairy cows. J. Dairy Sci. 85:397-405. https://doi.org/10.3168/ jds.S0022-0302(02)74087-3.

Dunn, T. R., T. L. Ollivett, D. L. Renaud, K. E. Leslie, S. J. LeBlanc, T. F. Duffield, and D. F. Kelton. 2018. The effect of lung consolidation, as determined by ultrasonography, on first-lactation milk production in Holstein dairy calves. J. Dairy Sci. 101:5404-5410. https://doi.org/10.3168/jds.2017-13870.

Dürr, J., and D. Norman. 2018. CDCB tools for improvement of the Jersey breed. Accessed Mar. 14, 2019. https://www.uscdcb.com/ wp-content/uploads/2018/07/20180630_AJCA_WJCB_Durr-2 .pdf.

Fleischer, P., M. Metzner, M. Beyerbach, M. Hoedemaker, and W. Klee. 2001. The relationship between milk yield and the incidence of some diseases in dairy cows. J. Dairy Sci. 84:2025-2035. https:/ /doi.org/10.3168/jds.S0022-0302(01)74646-2.

Gabler, M. T., P. R. Tozer, and A. J. Heinrichs. 2000. Development of a cost analysis spreadsheet for calculating the costs to raise a replacement dairy heifer. J. Dairy Sci. 83:1104-1109. https://doi .org/10.3168/jds.S0022-0302(00)74975-7.

Gilmour, A. R., B. J. Gogel, B. R. Cullis, S. J. Welham, and R. Thompson. 2015. ASReml User Guide. Release 4.1 Structural Specification. VSN International Ltd., Hemel Hempstead, UK.
Goff, J. P., and R. L. Horst. 1997. Physiological changes at parturition and their relationship to metabolic disorders. J. Dairy Sci. 80:1260-1268. https://doi.org/10.3168/jds.S0022-0302(97)76055 $-7$.

Gonzalez-Peña, D., N. Vukasinovic, J. J. Brooker, C. A. Przybyla, and S. K. DeNise. 2019. Genomic evaluation for calf wellness traits in Holstein cattle. J. Dairy Sci. 102:2319-2329. https://doi.org/10 $.3168 /$ jds.2018-15540.

Guard, C. L. 1996. Fresh cow problems are costly: Culling hurts the most. Hoard's Dairyman 141:8.

Gulliksen, S. M., K. Lie, T. Loken, and O. Osteras. 2009. Calf mortality in Norwegian dairy herds. J. Dairy Sci. 92:2782-2795. https:// doi.org/10.3168/jds.2008-1807.

Henderson, L., F. Miglior, A. Sewalem, J. Wormuth, D. Kelton, A. Robinson, and K. E. Leslie. 2011. Short communication: Genetic parameters for measures of calf health in a population of Holstein calves in New York State. J. Dairy Sci. 94:6181-6187. https://doi .org/10.3168/jds.2011-4347.

Heringstad, B., G. Klemetsdal, and J. Ruane. 2000. Selection for mastitis resistance in dairy cattle: A review with focus on the situation in the Nordic countries. Livest. Prod. Sci. 64:95-106. https://doi .org/10.1016/S0301-6226(99)00128-1.

Hertl, J. A., Y. H. Schukken, L. W. Tauer, F. L. Welcome, and Y. T. Gröhn. 2018. Does clinical mastitis in the first 100 days of lactation 1 predict increased mastitis occurrence and shorter herd life in dairy cows? J. Dairy Sci. 101:2309-2323. https://doi.org/10.3168/ jds.2017-12615.

Jamrozik, J., G. J. Kistemaker, B. J. Van Doormaal, A. Fleming, A. Koeck, and F. Miglior. 2016. Genetic evaluation for resistance to metabolic diseases in Canadian dairy breeds. Interbull Bull. 50:9-16.

Jamrozik, J., A. Koeck, F. Miglior, G. J. Kistemaker, F. S. Schenkel, D. F. Kelton, and B. J. Van Doormaal. 2013. Genetic and genomic evaluation of mastitis resistance in Canada. Interbull Bull. 47:43-51.

Jensen, L., K. Parker Gaddis, and D. Norman. 2019. Extending genomic evaluations to direct health traits in Jersey. Accessed Jul. 15, 2019. https://www.uscdcb.com/wp-content/uploads/2019/07/ JE-Health-Presentation-2.3-Laura-Jensen.pdf.

Kadarmideen, H. N., R. Thompson, and G. Simm. 2000. Linear and threshold model genetic parameters for disease, fertility and milk production in dairy cattle. Anim. Sci. 71:411-419. https://doi.org/ 10.1017/S1357729800055338.

Koeck, A., B. Heringstad, C. Egger-Danner, C. Fuerst, and B. FuerstWaltl. 2010. Comparison of different models for genetic analysis of clinical mastitis in Austrian Fleckvieh dual-purpose cows. J. Dairy Sci. 93:4351-4358. https://doi.org/10.3168/jds.2009-2955.

Koeck, A., F. Miglior, D. F. Kelton, and F. S. Schenkel. 2012. Health recording in Canadian Holsteins: Data and genetic parameters. J. Dairy Sci. 95:4099-4108. https://doi.org/10.3168/jds.2011-5127.

Kumar, U., A. P. Gawande, S. K. Sahatpure, M. S. Patil, C. K. Lakde, S. W. Bonde, P. L. Borkar, A. J. Poharkar, and B. R. Ramteke. 2015. Assessment of semen quality in pure and crossbred Jersey bulls. Vet. World 8:1266-1272. https://doi.org/10.14202/vetworld .2015.1266-1272.

Lean, I. J., P. J. DeGaris, D. M. McNeil, and E. Block. 2006. Hypocalcemia in dairy cows: Meta-analysis and dietary cation anion difference theory revisited. J. Dairy Sci. 89:669-684. https://doi .org/10.3168/jds.S0022-0302(06)72130-0.

Legarra, A., I. Aguilar, and I. Misztal. 2009. A relationship matrix including full pedigree and genomic information. J. Dairy Sci. 92:4656-4663. https://doi.org/10.3168/jds.2009-2061.

Liesegang, A., R. Eicher, M. L. Sassi, J. Risteli, M. Kraenzlin, J. L. Riond, and M. Wanner. 2000. Biochemical markers of bone formation and resorption around parturition and during lactation in dairy cows with high and low standard milk yields. J. Dairy Sci. 83:1773-1781. https://doi.org/10.3168/jds.S0022-0302(00)75048 $-\mathrm{X}$.

Liesegang, A., M. L. Sassi, J. Risteli, R. Eicher, M. Wanner, and J. L. Riond. 1998. Comparison of bone resorption markers during 
hypocalcemia in dairy cows. J. Dairy Sci. 81:2614-2622. https:// doi.org/10.3168/jds.S0022-0302(98)75819-9.

Mahmoud, M., T. Yin, K. Brügemann, and S. König. 2017. Phenotypic, genetic, and single nucleotide polymorphism marker associations between calf diseases and subsequent performance and disease occurrences of first-lactation German Holstein cows. J. Dairy Sci. 100:2017-2031. https://doi.org/10.3168/jds.2016-11767.

McCorquodale, C. E., A. Sewalem, F. Miglior, D. Kelton, A. Robinson, A. Koeck, and K. E. Leslie. 2013. Short communication: Analysis of health and survival in a population of Ontario Holstein heifer calves. J. Dairy Sci. 96:1880-1885. https://doi.org/10.3168/ jds.2012-5735.

McNeel, A. K., B. C. Reiter, D. Weigel, J. Osterstock, and F. A. Di Croce. 2017. Validation of genomic predictions for wellness traits in US Holstein cows. J. Dairy Sci. 100:9115-9124. https://doi.org/ $10.3168 /$ jds.2016-12323.

Miglior, F., A. Fleming, F. Malchiodi, L. F. Brito, P. Martin, and C. F. Baes. 2017. A 100-year review: Identification and genetic selection of economically important traits in dairy cattle. J. Dairy Sci. 100:10251-10271. https://doi.org/10.3168/jds.2017-12968.

Miglior, F., B. L. Muir, and B. J. Van Doormaal. 2005. Selection indices in Holstein cattle of various countries. J. Dairy Sci. 88:12551263. https://doi.org/10.3168/jds.S0022-0302(05)72792-2.

Misztal, I. 2005. Problems with the threshold model. Accessed Sep. 26, 2017. http://nce.ads.uga.edu/ ignacy/numpub/blupf90/winbin/ zs6/Readme.threshold_model.

Misztal, I. 2017. Breeding and Genetics Symposium: Resilience and lessons from studies in genetics of heat stress. J. Anim. Sci. 95:1780-1787. https://doi.org/10.2527/jas2016.0953.

Misztal, I., S. Tsuruta, D. Lourenco, I. Aguilar, A. Leggara, and Z. Vitezica. 2014. Manual for BLUPF90 family of programs. Accessed Jul. 27, 2016. http://nce.ads.uga.edu/wiki/lib/exe/fetch .php?media=blupf90_all4.pdf.

Misztal, I., S. Tsuruta, T. Strabel, B. Auvray, and T. Druet. 2002. BLUPF90 and related programs (BGF90). Page 743 in Proc. World Congr. Genet. Appl. Livest. Prod., Montpellier, France. Editions Quae, Montpellier, France.

Neuenschwander, T. F.-O., F. Miglior, J. Jamrozik, O. Berke, D. F. Kelton, and L. R. Schaeffer. 2012. Genetic parameters for producer-recorded health data in Canadian Holstein cattle. Animal 6:571-578. https://doi.org/10.1017/S1751731111002059.

Nicolazzi, E. L., J. W. Dürr, and G. R. Wiggans. 2018. Genomics in the U.S. dairy industry: Current and future challenges. Interbull Bull. 53:10-12.

Nieuwhof, G. J., H. D. Norman, and F. N. Dickinson. 1989. Phenotypic trends in herdlife of dairy cows in the United States. J. Dairy Sci. 72:726-736. https://doi.org/10.3168/jds.S0022-0302(89)79166-9.

Olde Riekerink, R. G. M., H. W. Barkema, D. F. Kelton, and D. T. Scholl. 2008. Incidence rate of clinical mastitis on Canadian dairy farms. J. Dairy Sci. 91:1366-1377. https://doi.org/10.3168/ jds.2007-0757.

Olson, K. M., B. G. Cassell, and M. D. Hanigan. 2010. Energy balance in first-lactation Holstein, Jersey, and reciprocal F1 crossbred cows in a planned crossbreeding experiment. J. Dairy Sci. 93:4374-4385. https://doi.org/10.3168/jds.2010-3195.

Olson, K. M., B. G. Cassell, M. D. Hanigan, and R. E. Pearson. 2011. Short communication: Interaction of energy balance, feed efficiency, early lactation health events, and fertility in first-lactation Holstein, Jersey, and reciprocal F1 crossbred cows. J. Dairy Sci. 94:507-511. https://doi.org/10.3168/jds.2010-3433.

Oltenacu, P. A., and D. M. Broom. 2010. The impact of genetic selection for increased milk yield on the welfare of dairy cows. Anim. Welfare 19(Suppl. 1):39-49.

Parker Gaddis, K. L., J. B. Cole, J. S. Clay, and C. Maltecca. 2014. Genomic selection for producer-recorded health event data in US dairy cattle. J. Dairy Sci. 97:3190-3199. https://doi.org/10.3168/ jds.2013-7543.

Parker Gaddis, K. L., J. H. Megonigal Jr., J. S. Clay, and C. W. Wolfe. 2018. Genome-wide association study for ketosis in US Jerseys using producer-recorded data. J. Dairy Sci. 101:413-424. https://doi .org/10.3168/jds.2017-13383.
Pedraza, J. R., and T. Vigil. 2014. 5 truths about raising Jerseys. Accessed Mar. 11, 2019. https://www.progressivedairy.com/topics/ calves-heifers/5-truths-about-raising-jerseys.

Philipsson, J., and B. Lindhé. 2003. Experiences of including reproduction and health traits in Scandinavian dairy cattle breeding programmes. Livest. Prod. Sci. 83:99-112. https://doi.org/10.1016/ S0301-6226(03)00047-2.

Philipsson, J., G. Ral, and B. Berglund. 1995. Somatic cell count as a selection criterion for mastitis resistance in dairy cattle. Livest. Prod. Sci. 41:195-200. https://doi.org/10.1016/0301 -6226(94)00067-H.

Pinedo, P. J., A. Daniels, J. Shumaker, and A. de Vries. 2014. Dynamics of culling for Jersey, Holstein, and Jersey $\times$ Holstein crossbred cows in large multibreed dairy herds. J. Dairy Sci. 97:2886-2895. https://doi.org/10.3168/jds.2013-7685.

Pryce, J. E., K. L. Parker Gaddis, A. Koeck, C. Bastin, M. Abdelsayed, N. Gengler, F. Miglior, B. Heringstad, C. Egger-Danner, K. F. Stock, A. J. Bradley, and J. B. Cole. 2016. Invited review: Opportunities for genetic improvement of metabolic diseases. J. Dairy Sci. 99:6855-6873. https://doi.org/10.3168/jds.2016-10854.

Rainard, P., G. Foucras, D. Boichard, and R. Rupp. 2018. Invited review: Low milk somatic cell count and susceptibility to mastitis. J. Dairy Sci. 101:6703-6714. https://doi.org/10.3168/jds.2018-14593.

Rauw, W. M., E. Kanis, E. N. Noordhuizen-Stassen, and F. J. Grommers. 1998. Undesirable side effects of selection for high production efficiency in farm animals: A review. Livest. Prod. Sci. 56:1533. https://doi.org/10.1016/S0301-6226(98)00147-X.

Rius-Vilarrasa, E., W. F. Fikse, E. Carlén, J.-Á. Eriksson, J. Pöso, U. S. Nielsen, and G. P. Aamand. 2018. Improved genetic evaluation of health traits using metabolic biomarkers in Nordic dairy cattle. Interbull Bull. 53:80-84.

Roche, J. R., and D. P. Berry. 2006. Periparturient climatic, animal, and management factors influencing the incidence of milk fever in grazing systems. J. Dairy Sci. 89:2775-2783. https://doi.org/10 .3168/jds.S0022-0302(06)72354-2.

Rollin, E., K. C. Dhuyvetter, and M. W. Overton. 2015. The cost of clinical mastitis in the first 30 days of lactation: An economic modeling tool. Prev. Vet. Med. 122:257-264. https://doi.org/10.1016/j .prevetmed.2015.11.006.

Rossini, K. 2004. Effects of calfhood respiratory and digestive disease on calfhood morbidity and first lactation production and survival rates. MS Thesis. Dairy Science Department, Virginia Tech, Blacksburg, VA.

Saborío-Montero, A., B. Vargas-Leitón, J. J. Romero-Zúñiga, and J. M. Sánchez. 2017. Risk factors associated with milk fever occurrence in grazing dairy cattle. J. Dairy Sci. 100:9715-9722. https:/ /doi.org/10.3168/jds.2017-13065.

Santman-Berends, I. M. G. A., T. J. G. M. Lam, J. Keurentjes, and G. van Schaik. 2015. An estimation of the clinical mastitis incidence per 100 cows per year based on routinely collected herd data. J. Dairy Sci. 98:6965-6977. https://doi.org/10.3168/jds.2015-9642.

Sargolzaei, M., J. P. Chesnais, and F. S. Schenkel. 2011. FImpute: An efficient imputation algorithm for dairy cattle populations. J. Dairy Sci. 94(E-Suppl. 1):421. (Abstr.)

Stanton, A. L., D. F. Kelton, S. J. LeBlanc, J. Wormuth, and K. E. Leslie. 2012. The effect of respiratory disease and a preventative antibiotic treatment on growth, survival, age at first calving, and milk production of dairy heifers. J. Dairy Sci. 95:4950-4960. https: //doi.org/10.3168/jds.2011-5067.

Svensson, C., and P. Liberg. 2006. The effect of group size on health and growth rate of Swedish dairy calves housed in pens with automatic milk-feeders. Prev. Vet. Med. 73:43-53. https://doi.org/10 .1016/j.prevetmed.2005.08.021.

Thomsen, P. T., and H. Houe. 2006. Dairy cow mortality. A review. Vet. Q. 28:122-129. https://doi.org/10.1080/01652176.2006 .9695218 .

US Jersey. 2016. Why Jerseys. Accessed Mar. 15, 2019. https://www .usjersey.com/Portals/0/AJCA/2_Docs/WhyJerseys2016.pdf.

van den Borne, B. H. P., G. van Schaik, T. J. G. M. Lam, and M. Nielen. 2010. Variation in herd level mastitis indicators between primi- 
and multiparae in Dutch dairy herds. Prev. Vet. Med. 96:49-55. https://doi.org/10.1016/j.prevetmed.2010.05.010.

VanRaden, P. M., J. B. Cole, and K. L. Parker Gaddis. 2018. Net merit as a measure of lifetime profit: 2018 revision. Accessed Mar. 13, 2019. https://aipl.arsusda.gov/reference/nmcalc-2018.htm.

VanRaden, P. M., A. H. Sanders, M. E. Tooker, R. H. Miller, H. D. Norman, M. T. Kuhn, and G. R. Wiggans. 2004. Development of a national genetic evaluation for cow fertility. J. Dairy Sci. 87:22852292. https://doi.org/10.3168/jds.S0022-0302(04)70049-1.

VanRaden, P. M., J. R. Wright, M. E. Tooker, and H. D. Norman. 2016. Values of selecting for cow and calf livability. Interbull Bull. 50:30-33.

Vukasinovic, N., N. Bacciu, C. A. Przybyla, P. Boddhireddy, and S. K. DeNise. 2017. Development of genetic and genomic evaluation for wellness traits in US Holstein cows. J. Dairy Sci. 100:428-438. https://doi.org/10.3168/jds.2016-11520.

Waltner-Toews, D., S. W. Martin, and A. H. Meek. 1986. The effect of early calfhood health status on survivorship and age at first calving. Can. J. Vet. Res. 50:314-317.

Weigel, K. A., and K. Barlass. 2003. Results of a producer survey regarding crossbreeding on US dairy farms. J. Dairy Sci. 86:41484154. https://doi.org/10.3168/jds.S0022-0302(03)74029-6.

Wellmann, R. 2018. optiSel: An R package for advanced optimum contribution selection. Page 54 in Proc. World Congress on Genetics Applied to Livestock Production. Auckland, New Zealand, Feb. $11-16,2018$.
Wiggans, G. R., T. S. Sonstegard, P. M. VanRaden, L. K. Matukumalli, R. D. Schnabel, J. F. Taylor, F. S. Schenkel, and C. P. Van Tassell. 2009. Selection of single-nucleotide polymorphisms and quality of genotypes used in genomic evaluation of dairy cattle in the United States and Canada. J. Dairy Sci. 92:3431-3436. https: //doi.org/10.3168/jds.2008-1758.

Yao, C., K. A. Weigel, and J. B. Cole. 2014. Short communication: Genetic evaluation of stillbirth in US Brown Swiss and Jersey cattle. J. Dairy Sci. 97:2474-2480. https://doi.org/10.3168/jds .2013-7320.

Zwald, N. R., K. A. Weigel, Y. M. Chang, R. D. Welper, and J. S. Clay. 2004a. Genetic selection for health traits using producerrecorded data. I. Incidence rates, heritability estimates, and sire breeding values. J. Dairy Sci. 87:4287-4294. https://doi.org/10 .3168/jds.S0022-0302(04)73573-0.

Zwald, N. R., K. A. Weigel, Y. M. Chang, R. D. Welper, and J. S. Clay. 2004b. Genetic selection for health traits using producer-recorded data. II. Genetic correlations, disease probabilities, and relationships with existing traits. J. Dairy Sci. 87:4295-4302. https: //doi.org/10.3168/jds.S0022-0302(04)73574-2.

\section{ORCIDS}

D. Gonzalez-Peña @i https://orcid.org/0000-0003-4846-7569

N. Vukasinovic ๑ https://orcid.org/0000-0002-5514-826X 